\title{
Fiscal Divergence and Current Account Imbalances in Europe
}

\author{
(August 30 2012)
}

\author{
Gunther Schnabl \\ Leipzig University \\ Institute for Economic Policy and CESifo \\ Grimmaische Str. 12 \\ D-04109 Leipzig \\ (schnabl@wifa.uni-leipzig.de)
}

\author{
Timo Wollmershäuser \\ Ifo Institute, University of Munich and \\ CESifo \\ Poschingerstr. 5 \\ D-81679 München \\ (wollmershaeuser@ifo.de)
}

\begin{abstract}
Since the breakdown of the Bretton Woods System diverging current account positions in Europe have prevailed. Whereas the Southern and Western European countries have tended to run current account deficits, the current accounts of the Central and Northern European countries, in particular Germany, have tended to be in surplus. The paper scrutinizes the role of diverging fiscal policy stances on current account (im-)balances in Europe since the early 1970s under alternative institutional monetary arrangements (floating exchange rates, European Monetary System, and European Monetary Union). The paper sheds light on the interaction of fiscal and monetary policies with respect to their impact on current account balances and analyses the role of exchange rates and credit mechanisms as adjustment mechanisms for current account imbalances. Pooled panel regressions reveal a robust impact of fiscal policy divergence on European current account imbalances, which is mainly independent from the exchange rate regime. An impact of credit mechanisms (reserve accumulation, changes in TARGET2 balances) for the financing of current account imbalances is identified.
\end{abstract}

Keywords: Europe, EMU, EMS, current account imbalances, exchange rate adjustment, credit mechanisms, European debt crisis.

JEL classification: H62, F32, F33, F42. 


\section{Introduction}

The smoldering European debt crisis is rooted in persistently diverging current account balances and thereby strongly diverging net international investment positions in Europe. After the turn of the millennium fast rising and persistent current account surpluses of Germany (and some of its smaller neighboring countries) have been matched by rising and persistent current account deficits of Southern, Western and Eastern European countries. Unidirectional capital flows from the center to the periphery financed increases of unit labor costs in the periphery countries and thereby triggered real appreciations of the abolished national currencies of the later crisis countries.

The origins of rising intra-European current account imbalances and the European sovereign debt crisis have been linked to random shocks (De Grauwe 2010) or the 1999 introduction of the common European currency, which facilitated intra-euro area capital flows (Berger and Nitsch 2011). Alternative approaches see macroeconomic policy behavior at the roots of the current crisis. Monetary policy can be seen as the main determinant of speculative international capital flows and excessive risk taking (Hoffmann and Schnabl 2011). Merler and Pisani-Ferry (2012) provide theoretical evidence that divergent fiscal policy stances in Europe for real exchange rate divergence and current account imbalances since the turn of the millennium. Sinn and Wollmershäuser (2012) have stressed the role of the TARGET2 payment system as an implicit credit mechanism for current account deficits within the European Monetary Union since the outbreak of the European sovereign debt crisis.

Previous empirical research on the impact of fiscal policy behavior on current account balances is either based on multi-country panels or single country studies. For instance, the panel regressions of Chinn and Prasad (2003) find a positive correlation between government budget deficits and current account deficits for a sample of industrial and developing countries. Kim and Roubini (2008) do not trace any evidence for a twin deficit hypothesis in the US based on historical data. Abbas et al. (2010) find a significant positive impact of budget deficits on current account positions based on panel regressions and vector autoregressions for a sample of low and high-income countries. 
We extend previous research in three regards. First, we focus on the impact of divergent fiscal policy stances on current account imbalances in Europe. Second, we approach the research question from a historical perspective since the breakdown of the Bretton Woods System, controlling for different institutional monetary frameworks, i.e. a high degree of exchange rate flexibility between 1973 and 1978, the European Monetary System (EMS) (1979-1998) and the European Monetary Union (EMU) (since 1999). Third, we analyze the impact of diverging fiscal policy stances on current account positions controlling for the interaction of fiscal and monetary policy as well as for the impact of institutionalized and implicit credit mechanisms for current account deficits.

The investigation provides evidence that heterogeneous fiscal policy behavior is at the root of current account imbalances in Europe, with the dimension being contingent on the monetary policy stance of the creditor country and the design of the credit mechanism for current account deficits. This implies that with the start of the EMU the Maastricht fiscal criteria have failed to unify fiscal policy stances to prevent crisis-prone current account imbalances. To cure this Achilles' heel of the EMU fiscal policies would have to take a more active role towards smoothing out asymmetric economic development within the EMU.

\section{Current Account and Fiscal Divergence from a Historical Perspective}

The interaction of fiscal policy stances and current account positions can be approached from two angles. First, from a single country perspective based on income identities, the current account balance is equivalent to the difference between aggregate saving and investment. Given constant private saving and investment, changes in the public saving behavior (government spending minus tax income) are equivalent to changes in the current account position. Rising public deficits are linked to rising current account deficits (twin deficit hypothesis) (see for instance Chinn and Prasad 2003, Abbas et al. 2010).

Second, the divergence of current account balances between two (or a group of) countries can be understood as the outcome of divergent fiscal policy paths as observed 
in Europe after the turn of the millennium (Merler and Pisani-Ferry 2012). A restrictive fiscal policy stance in Germany combined with expansionary fiscal policy stances in a set of other $\mathrm{E}(\mathrm{M}) \mathrm{U}$ member states triggered the rise of unidirectional capital flows from Germany to the $\mathrm{E}(\mathrm{M}) \mathrm{U}$ periphery and thereby rising current account imbalances in Europe. During this time period, the change of public inter-temporal optimization patterns was linked to changes in the private inter-temporal optimization patterns into the same direction, thereby aggravating current account imbalances in Europe.

It will be shown that inter-temporal optimization behavior in Europe not only hinge on national fiscal policy behavior and its impact on private net saving behavior, but also on the availability of international credit to finance current account deficits. Credit mechanisms can be understood as institutionalized part of international monetary agreements (such as in the EMS), changes in foreign reserve positions of central banks, or monetary policy stances in the creditor country affecting private international capital flows.

\section{a. Current Account (Im-)balances from a Historical Perspective}

Figure 1 shows the current account balances of the European countries (excluding Central and Eastern Europe) from a historical perspective since the year 1960. It groups the European countries into Northern European countries clustered around Germany (Austria, Belgium, Denmark, Finland, Germany, Netherlands, Sweden, Switzerland) and into Southern and Western European countries (France, Greece, Italy, Ireland, Portugal, Spain, UK). ${ }^{1}$ The grouping is based on different intertemporal preferences: A preference for comparatively high saving rates, price stability, tight fiscal policy stances, high investment and export driven growth in the North and a preference for comparatively high consumption, inflation, expansionary fiscal policy stances and net capital imports in the South and West. Germany is listed not only as part of the North, but also separately because of its crucial role for current account imbalances in Europe, in particular since the turn of the millennium.

1 Luxemburg and Norway are excluded from the sample as they are important outliers. 
Figure 1 reveals that from a cross-country perspective a tendency towards current account surpluses in the North is matched by comparatively high current account deficits in the South and West. The current account divergence in Europe is amplified starting from the 1990s. The current account surpluses of the smaller Northern European countries rise since the early 1990s (possibly linked to the German unification process), the deficits of the Southern and Western European countries rise starting from the late 1990s. Germany stands out as the largest country in Europe with a strong historical tendency for running current account surpluses with the major exception of a ten-year period after its unification and a soaring current account surplus starting from the year 2001.2 As shown in Figure 2 in terms of nominal values current account imbalances in Europe soared starting from the year 2001.

The European integration process forged these two country groups together, driven by the mutual interest of trade integration. The markets of the consumption-prone countries in the South and the West were opened up to the export-oreinted countries in the North (in particular Germany). Whereas the mutual interest of complementary intertemporal preferences in Europe remained widely unchanged (with the major exception of a ten years period after the German unification) the size of the current account deficits (and surpluses) in Europe hinged on the international financing conditions, i.e. intra-European private capital flows as well as public credit mechanisms for current account deficits. Figure 3 reveals the average size of current account deficits and surpluses under different institutional monetary frameworks independent from the compass point. It shows that the size of average current account deficits measured in percent of GDP gradually increased over time, soaring after the euro introduction.

During the 1950s and 1960s when private intra-European capital mobility was strongly restricted - inter alia linked to the missing convertibility of the European currencies up to the year 1958 - the international monetary relations in Europe were organized under the umbrella of the Bretton Woods System (BWS). The BWS treaties incorporated a credit mechanism, which allowed countries with balance of payments deficits to

2 The only major period of inversed current account positions was triggered by the German unification, when Germany turned into a net capital and goods importer due to high investment and consumption in the new eastern part of Germany. This period lasted about one decade from 1991 up to the year 2001, when the German current account balance started to turn strongly positive again (Schnabl and Zemanek 2011). 
postpone monetary and fiscal tightening without being forced into exchange rate adjustment (Genberg and Swoboda 1993). The credit mechanism incorporated a quantitative credit ceiling based on the deposited quota, a restriction concerning the time frame - usually from 18 up to 60 months -, as well as conditionality concerning economic policy making, in particular with respect to fiscal policy behavior. Albeit the IMF treaties provided the possibility of discretionary revaluations of the dollar parities to adjust current account deficits, the changes of the parities required the coordination with the IMF members and remained comparatively rare. Given a low degree of international private capital mobility and given the tight restrictions concerning international public credit, current account deficits in Europe remained small at about $1 \%$ of GDP on average (see Figure 3).

During the following period of widely floating exchange rates (1973-1978) current account deficits in Europe increased - favored by an increase in intra-European capital mobility - to an average of $2 \%$ of GDP. As under bloc floating only a very rudimentary credit mechanism (labeled European Monetary Cooperation Fund) had been put in place (Gros and Thygesen 1994: 21-22), the financing of current account deficits in Europe can be assumed to have worked mainly via private capital flows. The high degree of exchange rate flexibility allowed for reiterated exchange rate realignments, including frequent exits from the core Deutsche Mark bloc.

The constitution of the European Monetary System (EMS) unified countries with different current account positions into a system with closer monetary cooperation. The EMS credit mechanism implicitly accepted current account divergence in Europe, but incorporated clear limits for credit provision (Gros and Thygesen 1992: 48-50): The Very Short-Term Facility provided unlimited credit to support foreign exchange intervention for 45 days (starting from the end of the month). ${ }^{3}$ This credit could be prolonged under certain conditions by a maximum of three months. Any automatic extension by an additional three months (extendable once) was limited to the size of debtor quotas in the so-called Short-Term Monetary Support, originally set at a maximum 14 billion ECU for debtor countries. The Medium-Term Financial Assistance

3 In effect central banks of strong currencies had the obligation not to restrict the amounts of their own currency used to defend the existing bilateral margins (Gros and Thygesen 1992: 49). Therefore, changes in foreign reserves de facto include international credit provision during this time period. 
(11 billion ECU) allowed for longer-term credit, but only in case of balance of payments deficits and if the stability of the Common Market was at risk.

Despite the clear limits concerning the credit provision in face of balances of payments deficits, the average current account deficits in Europe increased to close to 3\% of GDP. The EMS was subject to frequent exchange rate realignments (including several EMS exits and re-entries), which in the very most cases took place at the depreciation side versus the German mark as the informal EMS anchor currency (Gros and Thygesen 1992: 67-98). The incidental event of the German unification not only constituted an asymmetric, destabilizing shock for Europe and the European Monetary System. It temporarily stopped the structural tendency of Germany to finance European current account deficits for about 10 years. Current account positions of most European countries improved during this time period (Figure 1).

With advent of the euro the need for foreign exchange intervention and exchange rate adjustment in the face of current account deficits was formally eliminated for euro area member states. In contrast to BWS and EMS no formal credit mechanism was part of the treaties on the European Monetary Union. Nevertheless the current account deficits increased to unprecedented levels (Figure 2 and 3), financed by rising private intraEuropean capital flows starting from the year 2001 up to the outbreak of the sovereign debt crisis. During the crisis, current account adjustment only took place partially (Figures 1 and 2). Instead private capital flows to the crisis countries were substituted by public capital flows in form of rescue packages (IMF, European Commission, EFSF, ESM etc.) and changes in the TARGET2 balances of national central banks at the European Central Bank (Sinn and Wollmershäuser 2012). ${ }^{4}$ Figure 4 shows the rapid increase of TARGET2 imbalances since the outbreak of the crisis, taking over the role of foreign exchange intervention and the EMS credit mechanism in response to current account deficits and capital flight.

4 In contrast to Sinn and Wollmershäuser (2012), who argue that changes in TARGET2 balances finance current account deficits Bindseil and König (2011) argue that they reflect capital flight from crisis countries. In both cases TARGET2 serves as an automatic credit mechanism during crisis. 


\section{b. Heterogeneous Macroeconomic Policy Stances and Current Account Balances}

Given limited central bank independence there is a close link between the fiscal and the monetary policy stance, as governments finance expenditure via inflation (rather than via tax collection). For instance, in Southern Europe up to the start of the euro qualification period, expansionary fiscal policy stances tended to be financed via government bond purchases of the central bank. The resulting high inflation rates were matched by comparatively low saving rates and current account deficits. In contrast, in countries with independent central banks (such as Germany) public spending had to be financed by taxes, what allowed central banks to pursue a price stability-oriented monetary policy stance. The resulting low inflation rates tended to favour private saving both from a national perspective as well as from an international perspective based on current account surpluses.

Figure 5 shows the substantially lower budget deficits (excluding interest rate payments) in the North of Europe compared to the South and the West. The divergence of fiscal policy behaviour measured in budget balances (expenditure excluding interest rate payments - minus tax revenues) as percent of GDP narrows during the euro qualification period and strongly diverges after the turn of the millennium. Figure 6 shows structurally higher government expenditure as percent of GDP in the Northern European countries compared to the Southern and Western European countries during most of the observation period. Yet, over time, government expenditure as percent of GDP is rising faster in the Southern and Western European countries, indicating a more expansionary spending behaviour compared to the North. After the turn of the millennium up to the crisis the divergence of spending patterns accelerates, with the North getting tighter and the South and West getting (comparatively) more expansionary. In Germany, following fast rising government debt during the German unification process, the decline of government expenditure as a share of GDP in Germany starting from the mid 1990s stands out.

The question of how relative expansionary fiscal policy stances are translated into diverging current account positions hinges on the monetary policy stances in international creditor economies, as expansionary (tight) monetary policy encourages (discourages) expenditure / debt accumulation due to declining (rising) domestic 
interest rates. Expansionary (tight) monetary policy encourages (discourages) risk taking in international financial markets in form of rising private capital outflows (McKinnon 2012). During the Bretton Woods System expansionary monetary policy stances were prevented by tight exchange rate stability against the dollar (as long as US monetary policy remained restrictive). Limited international capital mobility and constrained institutionalized international credit mechanisms constituted a restriction on fiscal expansion and thereby current account deficits.

The shift towards exchange rate flexibility in the early 1970s allowed for more independence in national monetary and fiscal policy making during the 1970s. Monetary expansion and exchange rate flexibility in Europe reached its preliminary peak in the post war period. Government deficits and inflation rates increased. Given that capital markets in Europe started to be liberalized current account deficits in Europe rose, mainly financed by private capital flows, risk taking in international / intra-European financial was encouraged by expansionary monetary policies.

The European Monetary System did not stipulate any direct restrictions on monetary or fiscal behaviour, although tight bilateral parities with narrow bandwidths would have implied a close convergence in macroeconomic policy stances. A tight monetary policy stance in Germany - its small neighbouring countries maintaining stable exchange rates against the German Mark - put a ceiling on capital outflows from low inflation countries and thereby the financing of current account deficits of other European countries via private capital flows. Frequent realignments allowed for the adjustment of more expansionary monetary policy stances in other parts of Europe. The German unification can be understood as a sudden tightening of financing conditions in Europe as German capital exports dried out due to large financing needs in Germany underpinned by tight German monetary policy. Current account deficits in Europe (other than Germany) reached a historical low.

After the introduction of the euro the macroeconomic conditions can be assumed be inversed compared to the German unification boom. Divergent fiscal policy stances restrictive fiscal policy in Germany and fiscal expansion in many Southern, Western and Eastern European countries - was underpinned by a monetary expansion by the European Central Bank starting in the year 2001 (in response to the burst of the dotcom 
bubble). Fiscal austerity in Germany and expansionary monetary policy by the European Central Bank encouraged fast rising intra-European capital flows from Germany to a number of mostly Southern, Western und Eastern European countries, where current account deficits soared (Abad et al. 2012). During the crisis the private German capital flows to the later crisis countries were to large extent substituted by public capital flows to the crisis countries underpinned by monetary expansion. This helped to sustain current account imbalances in Europe (Figure 1 and 2).

Figures 6 and 7 provide first evidence on the relationship between current account and fiscal policy stances in Europe under alternative monetary arrangements. The straight lines indicate fitted values. Figure 6 suggests that the correlation between budget deficits and current account positions increased over time, with a very tight correlation since euro introduction. Figure 7 associates the changes of government spending as percent of GDP over the previous year with the current account positions. Similarly to the budget deficits the correlation between both variables is increasing over time, with a very tight relationship for the period between 1999 and 2011. As Figures 6 and 7 do not control for the impact of other macroeconomic determinants of current account positions such as monetary policy stances, credit mechanisms and exchange rate adjustment we embark on panel estimations.

\section{Data and Model Specification}

Given the historical dimension of our investigation we use a panel of 15 western European countries. ${ }^{5}$ Current account balances $(\mathrm{ca})$ as endogeneous variables are compiled in percent of nominal GDP. We use overall current account balances as bilateral current account balances are not available for the whole time period. This approach is in line with the assumption that country-specific macroeconomic policy behavior is reflected in overall current account balances rather than bilateral current account balances versus specific countries.

5 Austria, Belgium, Denmark, Finland, France, Germany, Greece, Ireland, Italy, Netherlands, Portugal, Spain, Sweden, Switzerland, United Kingdom. Luxemburg and Norway are removed from the sample are they constitute major outliers. The Central, Eastern and Southeastern European countries are not included in the sample as this would considerably shorten the observation period. 
The fiscal policy stances are proxied in terms of government net lending in percent of GDP (gdef) and government expenditure in percent of GDP (gexp) (as shown as countrygroup averages in Figures 5 and 6). General government net lending as a proxy for the fiscal policy stances reflects the income identity approach to current accounts as well as the Maastricht general government deficit criterion. The downside is that government income via inflation tax or during speculative booms can hide expansionary fiscal policy stances and their impact on private saving and investment decisions. Therefore cyclically adjusted government expenditure is used as an alternative proxy for the fiscal policy stance. A relative rise (decline) in the government expenditure as percent of GDP indicates relative expansionary (restrictive) expenditure patterns. Interest payments are subtracted from government expenditure as they reflect past lending habits and monetary policy stances rather than actual spending. Both proxies for the fiscal policy stance are cyclically adjusted by expressing them in terms of potential GDP instead of actual GDP. ${ }^{6}$

National monetary policy stances are proxied by real short-term (money market) interest rates (i_real). In a time series framework this approach allows capturing both changes in the monetary policy stance as well as the asymmetric outcome of supranational monetary policy in the face of diverging national inflation rates. Nominal exchange rate adjustment to cope with current account deficits is captured by percent nominal exchange rate changes of national currencies versus the previous year (based on year-end values) against the German mark and later against the euro (dexchg). This reflects the notion that the German Mark served as an informal anchor currency in Europe after the break down of the Bretton Woods System up to the introduction of the euro (Herz 1994). For the years of EMU membership the exchange rate variable is set equal to zero. For Germany, up to the EMU entry, the arithmetic average of the exchange rate change of the German Mark versus the French Franc, the Italian Lira and the British Pound is used as a proxy for exchange rate changes.

Previous to the entry in the European Monetary Union and in the current non-EMU member states exchange rate stabilization has been a way of financing current account

6 This approach of cyclical adjustment does not control for cyclical effects caused by speculative booms as they took for instance place in the real estate or financial sectors of Spain and Ireland or in government spending and consumption of Greece between 2001 and 2008 (see Schnabl 2012). 
deficits without outright exchange rate realignment or adjustment of macroeconomic policy stances. Changes in foreign reserves can be assumed to include credit provided within the European Monetary System, as it affected the foreign reserve positions of central banks (see footnote 3). Changes in foreign reserves are measured in terms of the absolute changes of the year-end values against previous year-end values divided by GDP (dres). Changes in TARGET2 balances of the national central banks of EMU member states at the European Central Bank (change of year-end value against previous year-end value) divided by GDP are used as proxy for an informal credit mechanism in the EMU (dtarget). This variable is augmented by the country specific rescue packages provided to individual member states since the start of the European debt crisis.

We add several control variables, which have been identified as important determinants of current account positions in Europe. Unit labor costs - reflecting productivity increases and wage policies - are proxied by real unit labor costs in percent changes versus the previous year (drulc). Furthermore, global current account positions have been influenced by US current account balances and US monetary policy decisions (Freitag and Schnabl 2012). As capital exports of the European surplus countries can be assumed to be either absorbed by the US or by (potential) European deficit countries, the bilateral current account position of the US versus Europe as percent of US GDP ( $c a_{-} u s$ ) is included as a control variable. The money market rate of the US (federal funds rate) is used as a proxy for the US monetary policy stance (i_us).

The estimations are based on yearly data, because data for fiscal spending and budget deficits are only available on a yearly basis. The observation period ranges from the year 1973 - when the Bretton Woods System collapsed up to the year 2011. We excluded the 1960s from our estimations since harmonized data in particular on the fiscal policy stance is unavailable for many countries. Panel unit roots tests reveal that there is no concern about unit roots in the data set. Dummies are compiled for euro area membership (_euro), the period after 2001 when the current account imbalances in Europe started to hike (_2001), for countries with structural current account surpluses after 1999 (_core), for membership in the EMS and the European Exchange Rate Mechanism II (_ems) and for countries being neither members of the EMS nor ERMII (_nonems). 
To explain the impact of heterogeneous fiscal policy stances in Europe on current account positions under different exchange rate arrangements we use the following model:

$$
c a_{i t}=\gamma_{i}+\varphi g_{i t}+\delta v_{i t}+\varepsilon_{i t}
$$

where $c a_{i t}$ is the vector of yearly overall current account positions from 1973 to 2011 for the countries $i$. The explanatory variables consist of the proxies for fiscal spending $g_{i t}$ and the matrix of control variables $v_{i t}$. As we regard macroeconomic policy making as exogenous we use a standard panel fixed effects model as estimation framework.

\section{Estimation Results}

The estimation results of equation (1) are reported in Table 2 to Table 5 in different specifications. Table 2 reports the regressions results with cyclically adjusted government expenditure (excluding interest payments) as proxy for the fiscal policy stance, i.e. excluding tax revenues etc. The baseline regression (1) reports overall averages for the whole observation period from 1973 to 2011. The impact of government expenditure on the national current account position is significant at the one percent level, with rising expenditure being linked to worsening current account positions. The monetary policy stance proxied by the real interest rate is insignificant as determinant of current account positions.

Nominal exchange rate adjustment, changes in foreign reserves and TARGET2 balances (incl. rescue packages) have no significant impact on current account positions in Europe for the whole observation period. Yet, a relative increase (decline) of real unit labor costs is linked to a worsening (improving) current account position, significant at the 5\% level. ${ }^{7}$ The European current account positions have to be seen in a global context. US monetary policy and the US current account position versus Europe have a highly significant impact on national European current account positions. Monetary

\footnotetext{
7 This suggests that private austerity is systematically linked to public austerity with a symmetric impact
} on the current account position. 
expansion in the US is linked to rising capital outflows from Europe and thereby improving current account positions, which are matched by a rising current account deficit of the US versus Europe.

Regression (2) tests for asymmetric effects of fiscal, monetary and wage policies since euro introduction by interacting the proxies for government expenditure, real interest rates and changes in unit labor costs with a dummy for euro area membership. The results suggest that the impact of diverging fiscal policies on diverging current account positions remains widely unchanged as the additional effect for euro area countries is comparatively small (albeit significant at the 1\% level). This implies that the Maastricht fiscal criteria have failed to make euro area member's fiscal policy stances converge to forestall current account imbalances in Europe.

In contrast, real interest rates are identified as an important transmission channel for current account imbalances in the euro area. Declining real interest rates set by the European Central Bank are significantly linked to worsening current account positions. Divergence in unit labor costs is identified as a second transmission channel for the rising current account imbalances in euro area countries. In contrast to the base line regression (1) changes in TARGET2 balances play a significant role for current account imbalances in the euro area, significant at the 1\% level. Exchange rate depreciation (appreciation) is linked to negative (positive) current account balances, significant at the five percent level.

Regression (2a) copes with the argument that the tremendous increase of the current account imbalances in Europe is linked to factors beyond euro introduction, for instance ECB interest rate cuts in response to the burst of the dotcom bubble starting from 2001 (Abad et al. 2012). To test for this hypothesis the proxies for government expenditure, real interest rates and unit labor costs are interacted with a dummy taking the value of unity starting from the year 2001 for all countries in the sample. In this specification the highly significant impact of divergent fiscal policies on European current account positions is unchanged since the year 2001. The changing impact of real interest rates (declining real interest rates imply a worsening of current account positions) remains in place for the period after 2001 for all European countries at highly significant levels, albeit at a smaller scale. The additional impact of diverging unit labor costs on the 
current account positions turns insignificant, suggesting that the transmission of current account balances via unit labor costs since the turn of the millennium is predominantly a phenomenon in euro area countries.

Regression (3) tests for asymmetric effects of the bilateral US current account balance versus Europe on countries with structural current account surpluses and non-euro area countries. The dummy (_core) takes the value of one for euro area countries having on average current account surpluses during their euro area membership (Austria, Belgium, Finland, Germany, the Netherlands). The highly negative coefficient indicates that this country group produced rising current account surpluses in response to rising US current account deficits. In contrast, the coefficient for the other European countries turns insignificant suggesting that they did not contribute in financing the US current account deficit versus Europe. This implies that the negative correlation between the US current account and the average European current account position in the regressions (1) and (2) is driven by the European structural current account surplus countries. A similar finding applies for the European non-euro area countries (Denmark, Sweden, Switzerland, UK), which are isolated based on the dummy (ca_us_noneuro), but at a lower significance level.

Regression (4) isolates asymmetric effects of US monetary expansion on euro area member states with structural current account surpluses and non-members of the euro area. Euro area members with structural current account surpluses are revealed to respond significantly stronger with their current account position to US interest rate cuts than the average of all countries in the sample. In contrast, non-members of the euro area respond significantly less to US interest rate cuts, but in the same direction.

Regression (5) analyses if under the European Monetary System and under widely flexible exchange rate regimes ${ }^{8}$ reserve accumulation and exchange rate realignments had a significantly different impact on current account positions in Europe. There is no statistical evidence that more exchange rate flexibility helps to cope with current account deficits (and surpluses), with divergent fiscal policies and diverging unit labor costs being identified as the main driving forces of current account imbalances in

8 The period from 1973-1978 for all countries in the sample and the non-EMS and non-EMU members afterwards. 
Europe. The policy implication is that the adjustment of current account imbalances requires a realignment of fiscal policy stances and unit labor costs rather than the adjustment of exchange rate parities.

Table 3 reports the regression results for cyclically adjusted public budget deficits (excluding interest payments) as a proxy for the fiscal policy stance. The results - albeit less pronounced - are by and large in line with the results reported for fiscal expenditure. Rising (declining) budget deficits are associated with worsening (improving) current accounts, significant at the 1\% percent level (regression (1)). Controlling for EMU membership or for the post-2001 period the coefficient for the remaining countries / time period gets insignificant. This implies that the results are driven by a strong impact of budget deficits on current account balances for euro area member states (regression (2)), alternatively for all European countries since the year 2001 (regression (2a)).

Similarly to the regression results reported in Table 2, monetary expansion is clearly linked to rising current account deficits (declining surpluses) for euro area countries and all countries in the sample since 2001. In contrast to Table 2 for the remaining observation period (before 2001 and for non-euro area countries) the link between real interest rates and current account balances is reversed, with low real interest rates being is linked to improved current account positions at a significantly smaller semielasticity.

As in Table 2, unit labor costs are an important determinant of current account balances in Europe, in particular linked to euro introduction or since the year 2001 respectively. In contrast to Table 2, changes of TARGET2 balances of national central banks at the European Central Bank get statistically insignificant with respect to their impact on the current account position. The impact of US monetary policy on European current account positions remains widely unchanged. US interest rate cuts are linked to improving current account positions in Europe. In contrast, there is no clear evidence for a systematic impact of the US current account position versus Europe on the European current account positions of single European countries. 
Based on the specifications presented in Table 2 and Table 3 six main findings are widely robust. (1) Diverging fiscal policy stances have been a main driving force of current account positions / imbalances in Europe since the 1970s. (2) Monetary expansion has contributed to a further worsening of current account deficits in euro area countries and / or in all countries since the year 2001. (3) Together with fiscal policy stances changes in relative unit labor costs have been an important driving force of rising current account imbalances, in particular in euro area countries. (4) Fiscal and wage policies (i.e. unit labor costs) point into the same direction, with public and private austerity being linked to an improved current account positions and vice versa. (5) Monetary conditions in the US and the US current account position have a significant impact on current account positions of European countries, in particular of European countries with current account surpluses. (6) TARGET2 balances at the European Central Bank contribute to the financing of current account imbalances in the euro area since the start of the European debt crisis.

Table 4 and Table 5 report the results for the time period since 1999 after the euro was introduced and current account divergence in Europe strongly increased. Reducing the time dimension of the panel and thereby stressing the cross-country dimension of the investigation yields less significant results. The results with government expenditure as proxy for fiscal consolidation provide again strong evidence that fiscal divergence in Europe being at the root of current account divergence. Monetary policy - proxied by national real interest rates - is confirmed as transmission mechanism of current account imbalances in Europe, as it is the case for diverging unit labor costs. These results are qualitatively the same for all countries in the sample after the year 2001 as in euro area countries. For the estimations based on budget deficits there are mainly no statistically significant results. This may be in line with the hypothesis, that due speculative booms in the later crisis economies, government deficits did not reflect the high degree of fiscal policy divergence in terms of spending patterns.

\section{Conclusion}

Since World War II Europe has been divided into two country groups with different philosophies concerning fiscal policy making, monetary policy making and intertemporal optimization. Whereas the countries in Southern and Western Europe had a 
preference for consumption and expansionary fiscal and monetary policies, the countries in the center preferred saving, investment, and comparatively tighter fiscal and monetary policy stances. The different macroeconomic policy stances were reflected in diverging current account balances, a tendency towards current account deficits in the South and West, and towards surpluses in the North.

Both country groups were forged together by the mutual interest of the European integration process. During the pre-stages for the common currency unsustainable current account deficits were prevented by tight restrictions in intra-European credit mechanisms, the possibility of exchange rate realignment and a tight monetary policy stance in Germany as the center of the European monetary system. In contrast, with the euro introduction these control mechanisms for structural current account deficits were removed and the Maastricht fiscal criteria failed to make fiscal policy stances converge. The outcome has been rising imbalances in European current accounts and a smoldering European debt crisis.

We have provided evidence that divergent fiscal policy stances are an important determinant of intra-European current account imbalances both before and after euro introduction. The adjustment of unit labor costs - which can be linked to the fiscal policy stance - has contributed to the divergence in the current account positions. After the year 2001 there is evidence that current account imbalances have been encouraged by an expansionary ECB monetary policy stance, which encouraged international risk taking. Furthermore, there is evidence of a significant impact of US monetary policy decisions and (thereby) the US current account balance on the current account balances of European countries. After the advent of the European debt crisis changes in TARGET2 balances of national central banks at the European Central Bank are likely to have contributed to sustain current account imbalances in Europe. We also provide evidence that since 1973 exchange rate adjustment has played only a minor role in coping with current account imbalances.

As in a monetary union fiscal divergence is at the roots of current account imbalances in Europe and as the Maastricht criteria have failed to unify fiscal policy stances in the euro area, we recommend to create a more coherent framework, which helps to eliminate asymmetric shocks (development) being created by fiscal divergence. A tighter 
coordination of fiscal policies with respect to the impact of current account imbalances can be a first step into this direction, i.e. current account deficit countries have to pursue a tighter fiscal policy stance, whereas surplus countries would have to embark on government spending. Furthermore, we recommend a tighter monetary policy stance, which discourages risk taking in intra-European financial markets. Only the combination of a convergence of fiscal policy stances in Europe and a tighter monetary policy stance of the European Central Bank will provide the necessary prerequisites for the consolidation of the current account imbalances and future crisis in Europe. This process would be facilitated by a tighter monetary policy stance in the US.

\section{References:}

Abad, Jose / Löffler, Axel / Schnabl, Gunther / Zemanek, Holger 2012: Fiscal Divergence and TARGET2 Imbalances in the EMU. University of Leipzig Working Paper 105.

Abbas, Ali / Bouhga-Hagbe, Jacques / Fatás, Antonio / Mauro, Paolo / Velloso, Ricardo 2010: Fiscal Policy and the Current Account. IMF Working Paper 10/121.

Bindseil, Ulrich / Koenig, Philipp 2011: The Economics of TARGET2 Balances. Humbolt University Berlin SFB 649 Discussion Paper 35.

Berger, Helge/ Nitsch, Volker 2010: The Euro's Effect on Trade Imbalances. IMF Working Paper $10 / 226$.

Chinn, Menzie / Prasad, Eswar 2003: Medium-Term Determinants of Current Accounts in Industrial and Developing Countries: An Empirical Exploration. Journal of International Economics 59, 47-76.

De Grauwe, Paul 2010: Crisis in the Eurozone and How to Deal with it. CEPS Policy Brief 204.

Genberg, Hans / Swoboda, Alexander 1993: The Provision of Liquidity in the Bretton Woods System. In: Bordo, Michael / Eichengreen, Barry (eds.): A Retrospective on the Bretton Woods Systems: Lessons for International Monetary Reform. University of Chicago Press, Chicago.

Gros, Daniel / Thygesen, Niels 1994: European Monetary Integration. From the European Monetary System to Economic and Monetary Union. Longman Group, London.

Herz, Bernhard 1994: Währungspolitische Asymmetrie im Europäischen Währungssytem. Nomos, Baden-Baden. 
Hoffmann, Andreas / Schnabl, Gunther 2011: National Monetary Policy, International Economic Instability and Feedback Effects - An Overinvestment View. Global Financial Markets Working Paper 19.

Kim, Soyoung / Roubini, Nouriel 2008:"Twin Deficit and Twin Divergence? Fiscal Policy, Current Account, and Real Exchange Rate in the U.S. Journal of Economic Literature 74, 362-383.

Merler, Silvia / Pisani-Feri, Jean 2012: The Simple Macroeconomics of North and South in EMU. Bruegel Working Paper 2012/12.

Sinn, Hans-Werner / Wollmerhäuser, Timo 2012: Target Loans, Current Account Balances and Capital Flows: the ECB's Rescure Facility. International Tax and Public Finance 19, 4, 468-508.

Schnabl, Gunther / Zemanek, Holger 2011: Inter-Temporal Savings, Current Account Imbalances and Asymmetric Shocks in a Heterogeneous European Monetary Union. Intereconomics 46, 3, 153-160. 
Figure 1: Average Current Account Balance in Western Europe

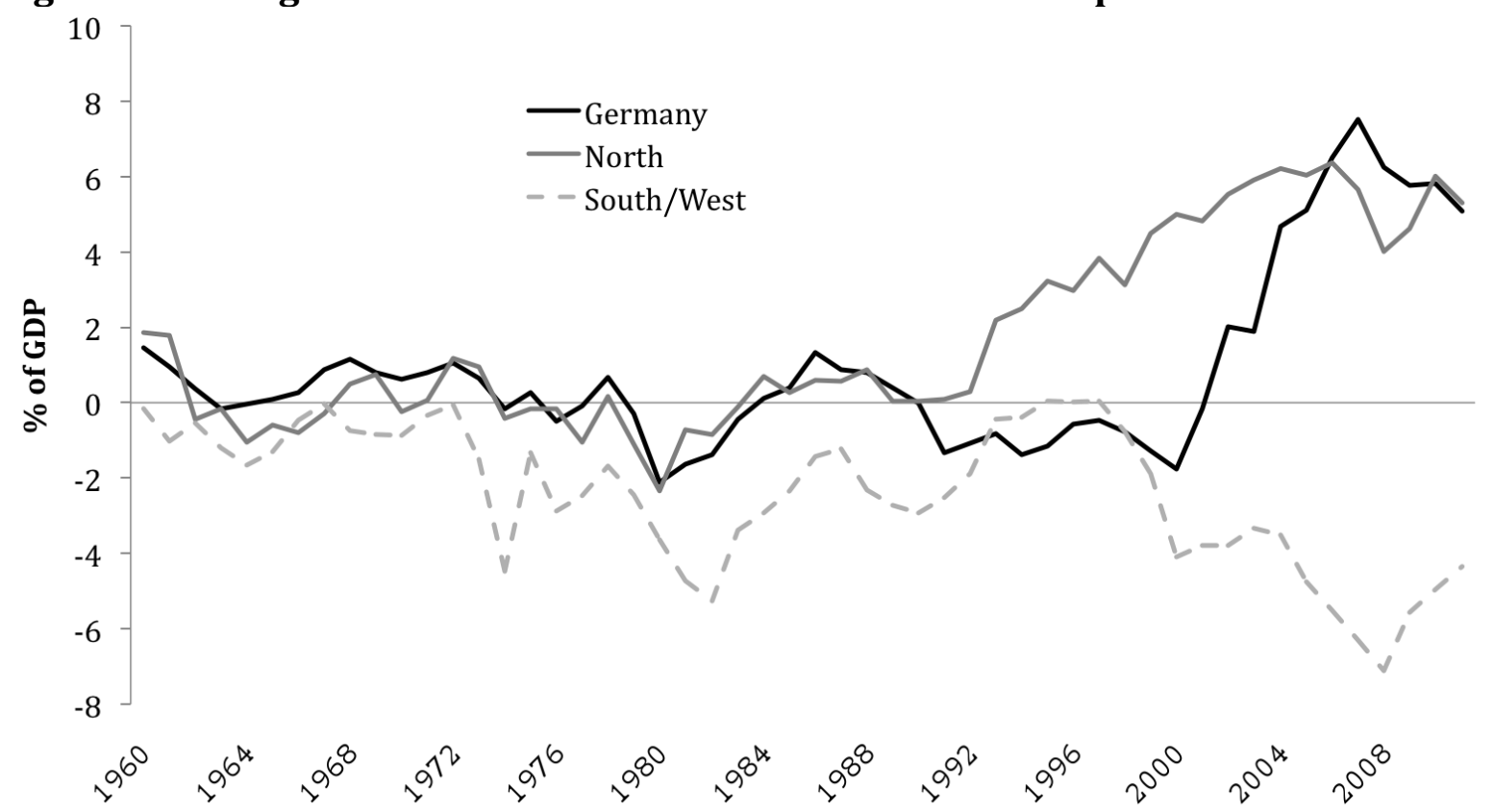

Source: European Commission AMECO database. North = Austria, Belgium, Denmark, Finland, Germany, Netherlands, Switzerland, Sweden. South/West = France, Greece, Italy, Ireland, Portugal, Spain, UK. Arithmetic averages.

Figure 2: Current Account Balances in Western Europe

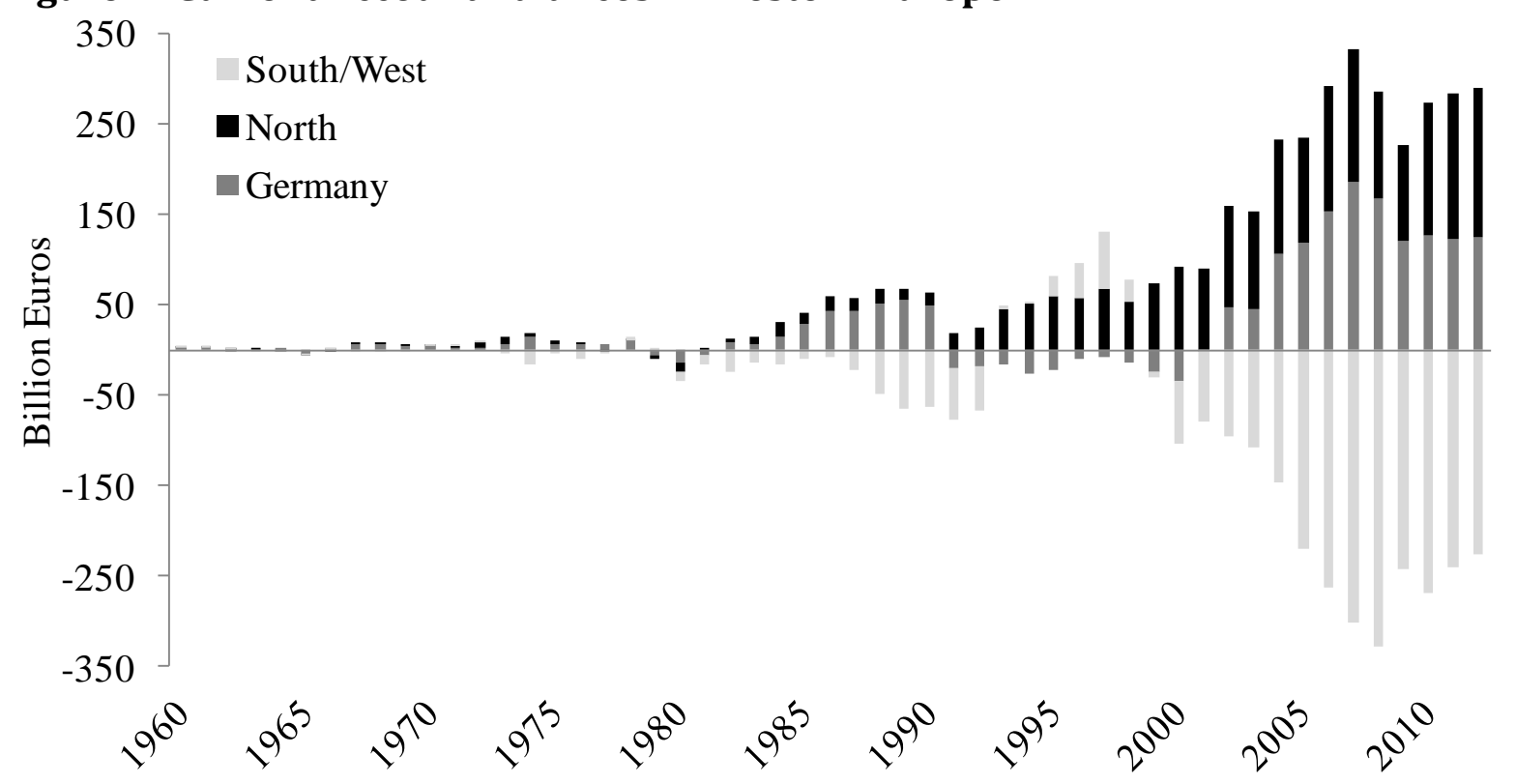

Source: IMF, European Commission AMECO database. 
Figure 3: Current Account Deficits by Country Groups

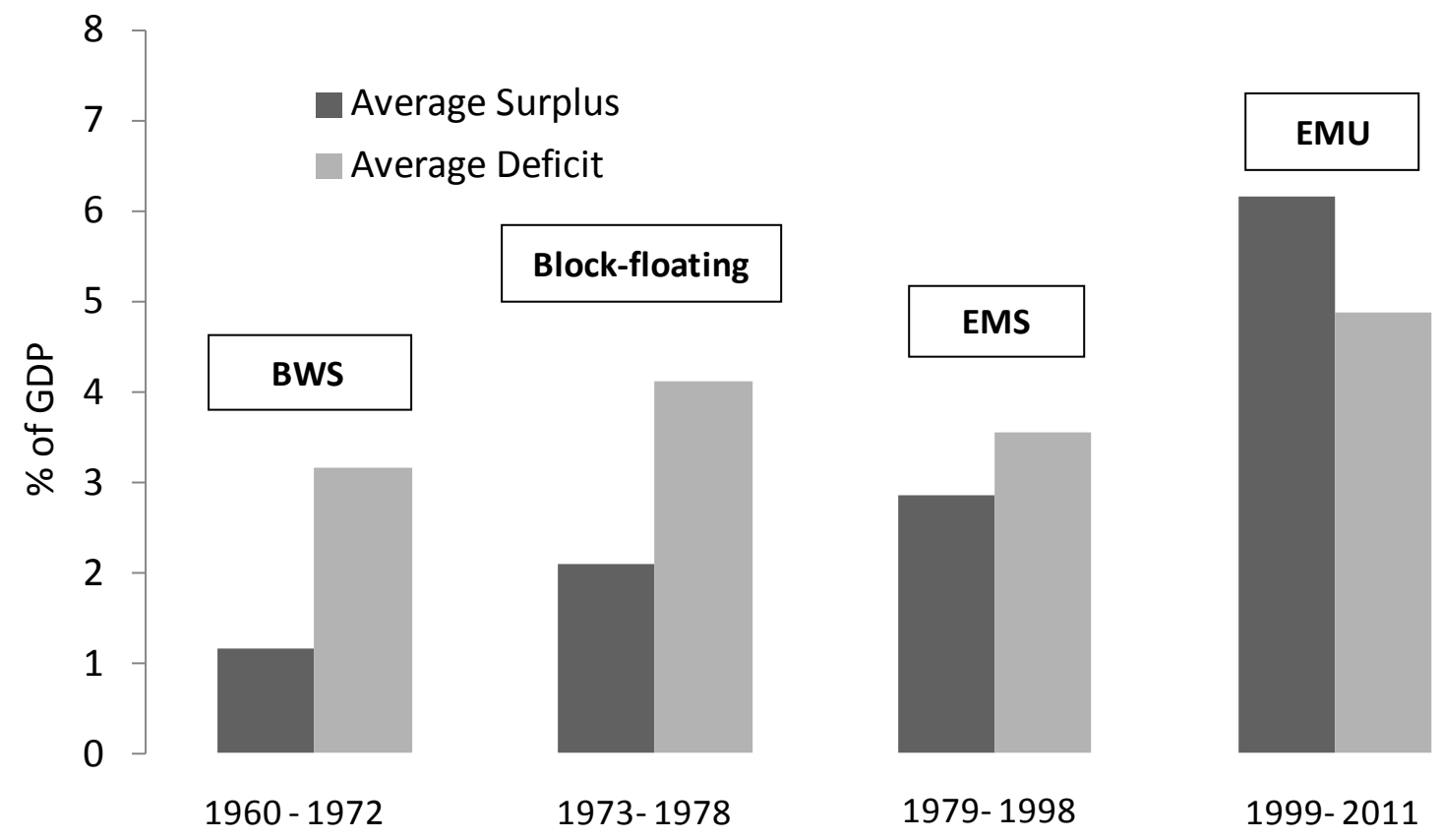

Source: IMF, European Commission AMECO database. Arithmetic averages.

Figure 4: National TARGET2 Balances at the ECB

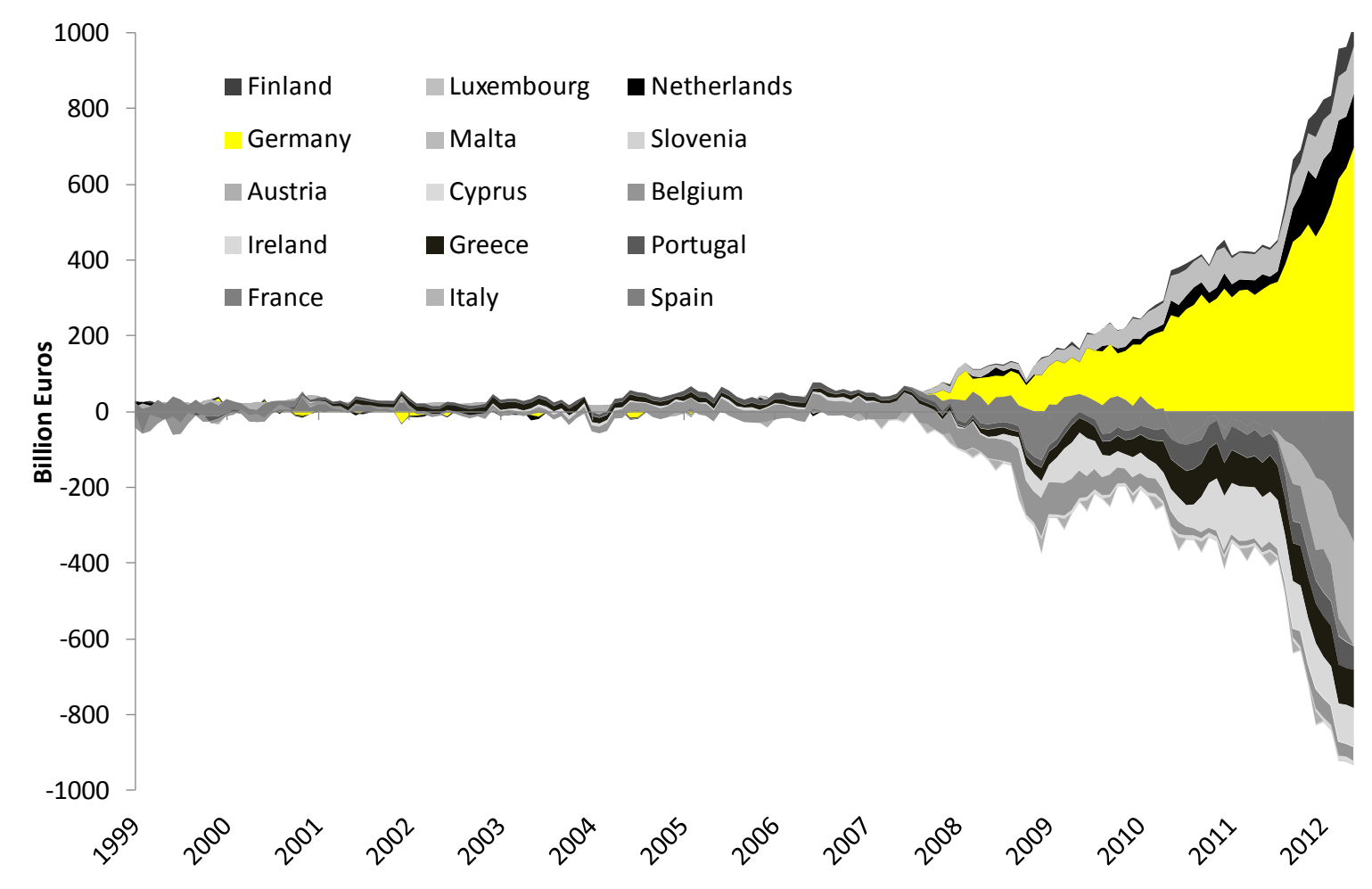

Source:

Ifo

Institute

(http://www.cesifo-

group.de/ifoHome/policy/Haftungspegel.html). 
Figure 5: Cyclically Adjusted Government Net Lending by Country Group in \% of Potential GDP

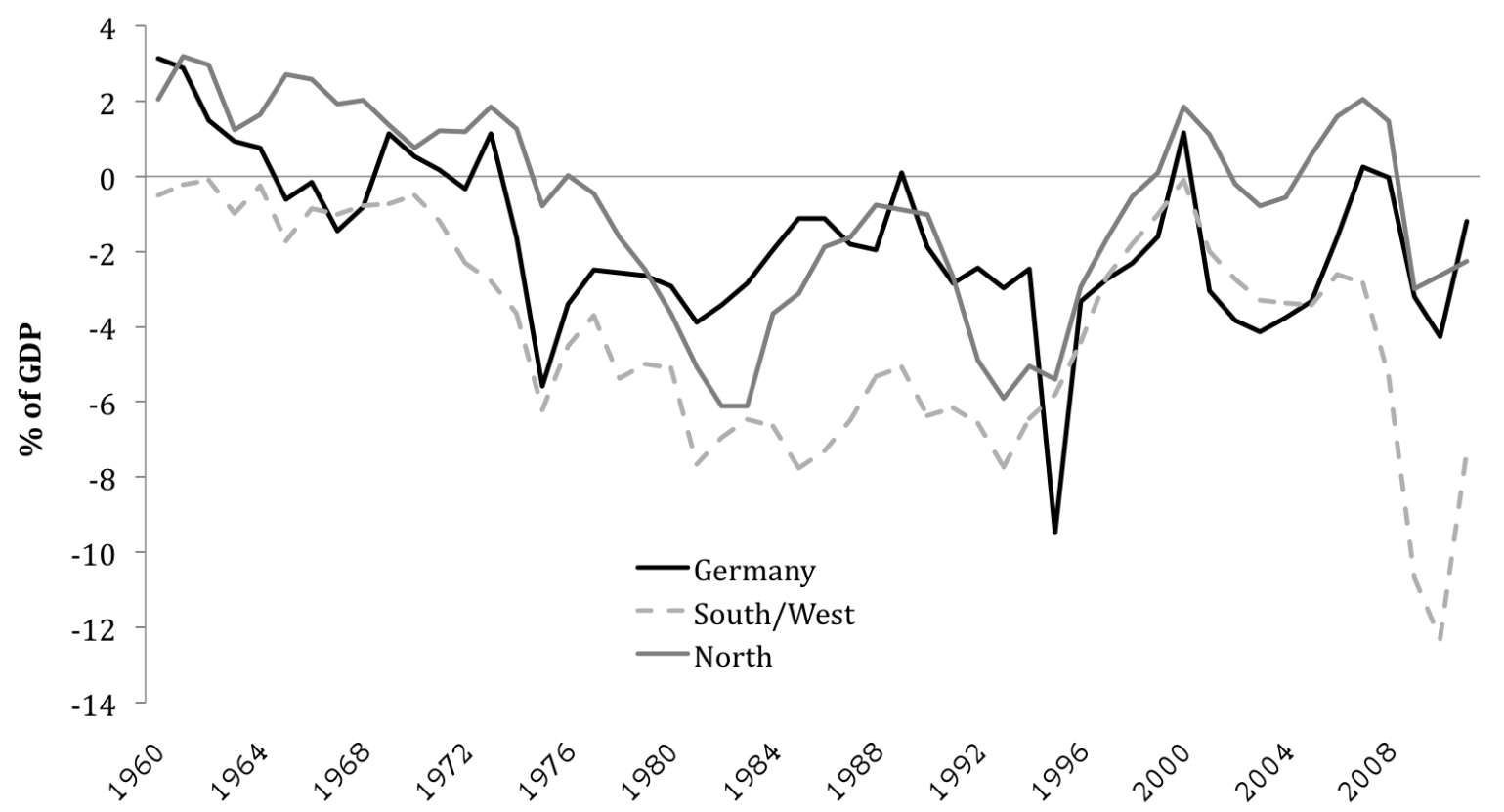

Source: OECD Economic Outlook No. 90.

Figure 6: Cyclically Adjusted Government Expenditure by Country Group (Excluding Interest Payments) in \% of Potential GDP

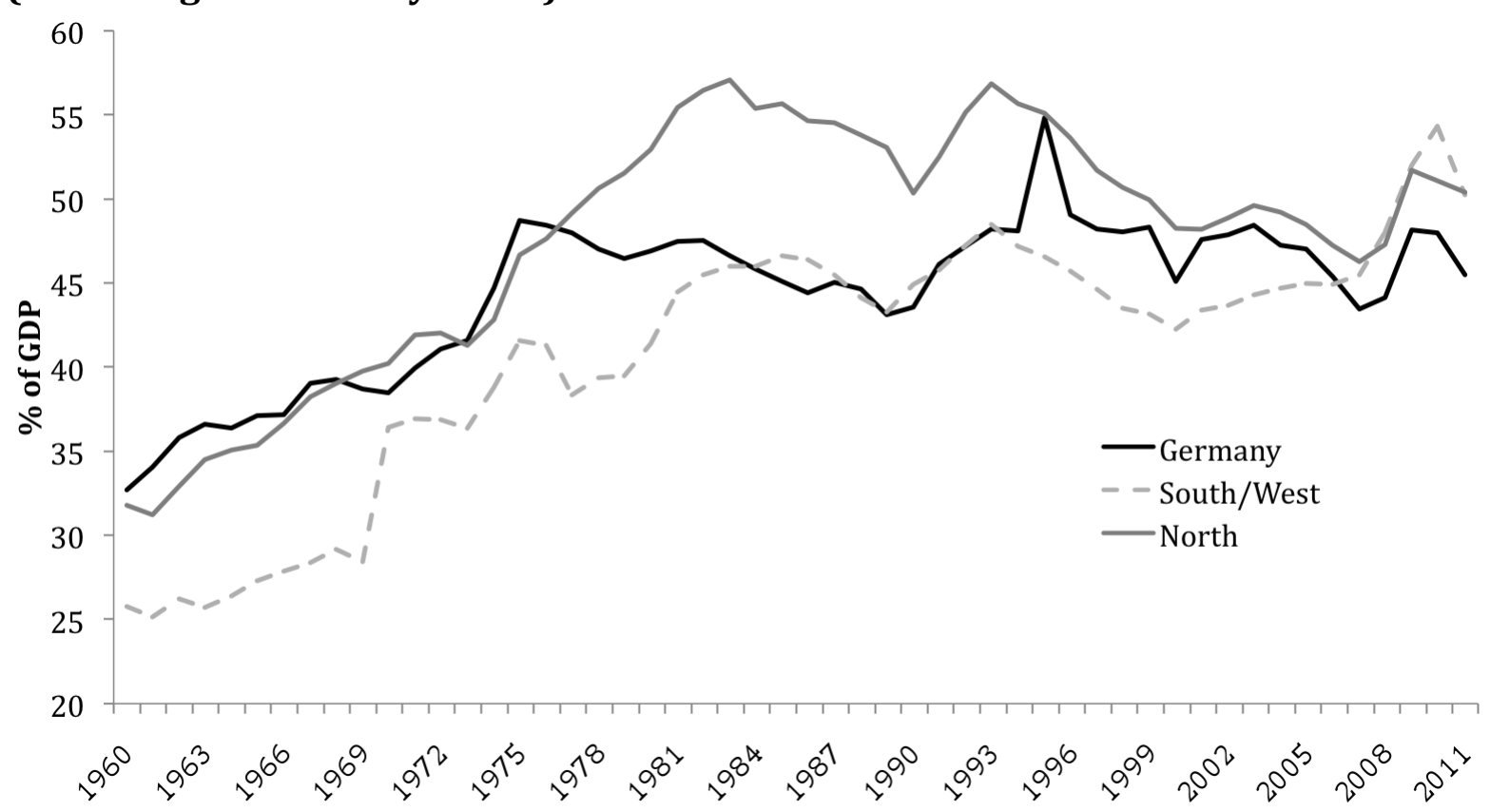

Source: OECD Economic Outlook No. 90. 
Figure 7: Changes in Government Expenditure and Current Accounts
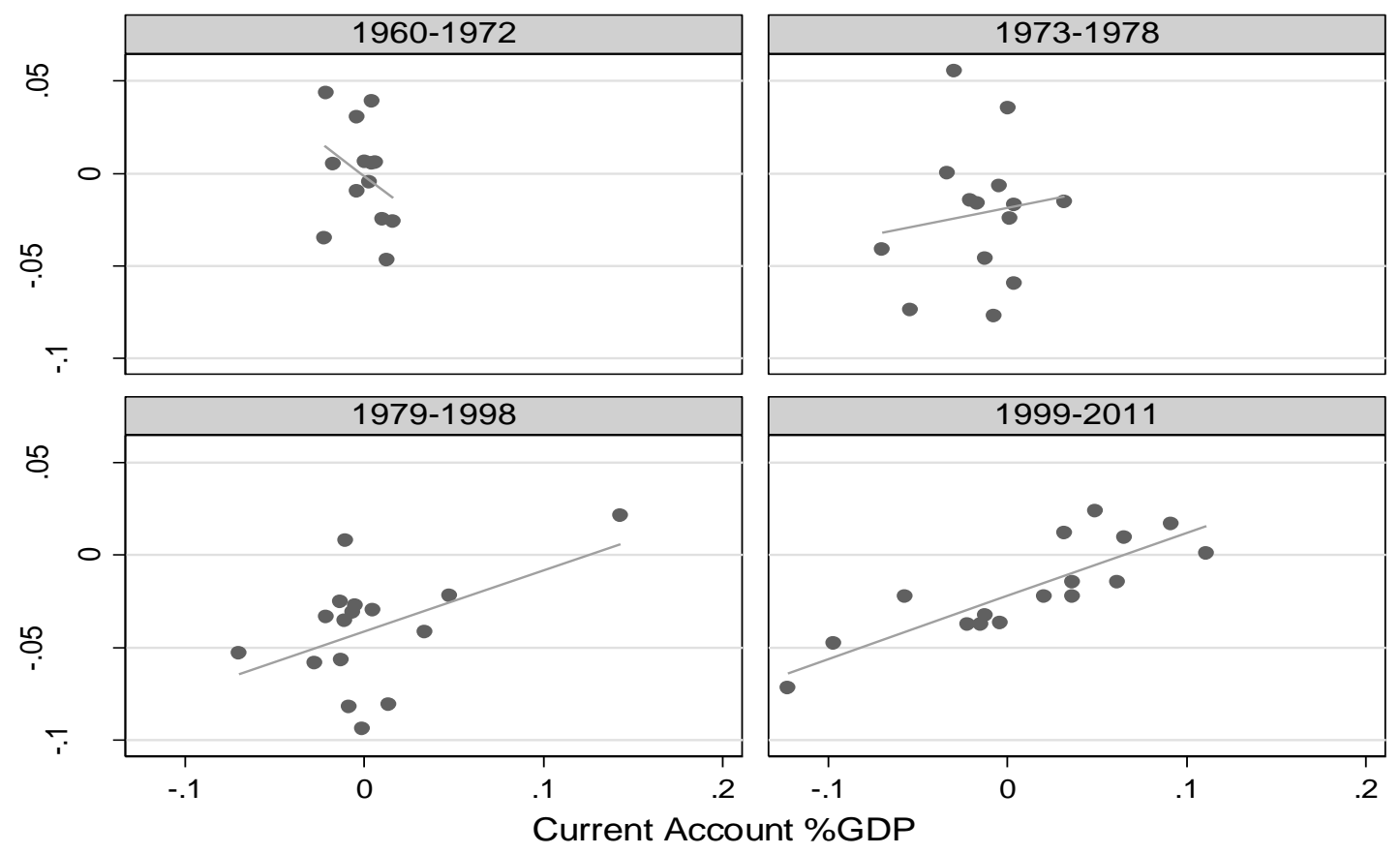

Source: OECD Economic Outlook No. 90, European Commission AMECO database. Changes calculated in percentage points of GDP versus previous year. Straight lines indicate fitted values.

\section{Figure 8: Budget Deficits and Current Accounts}
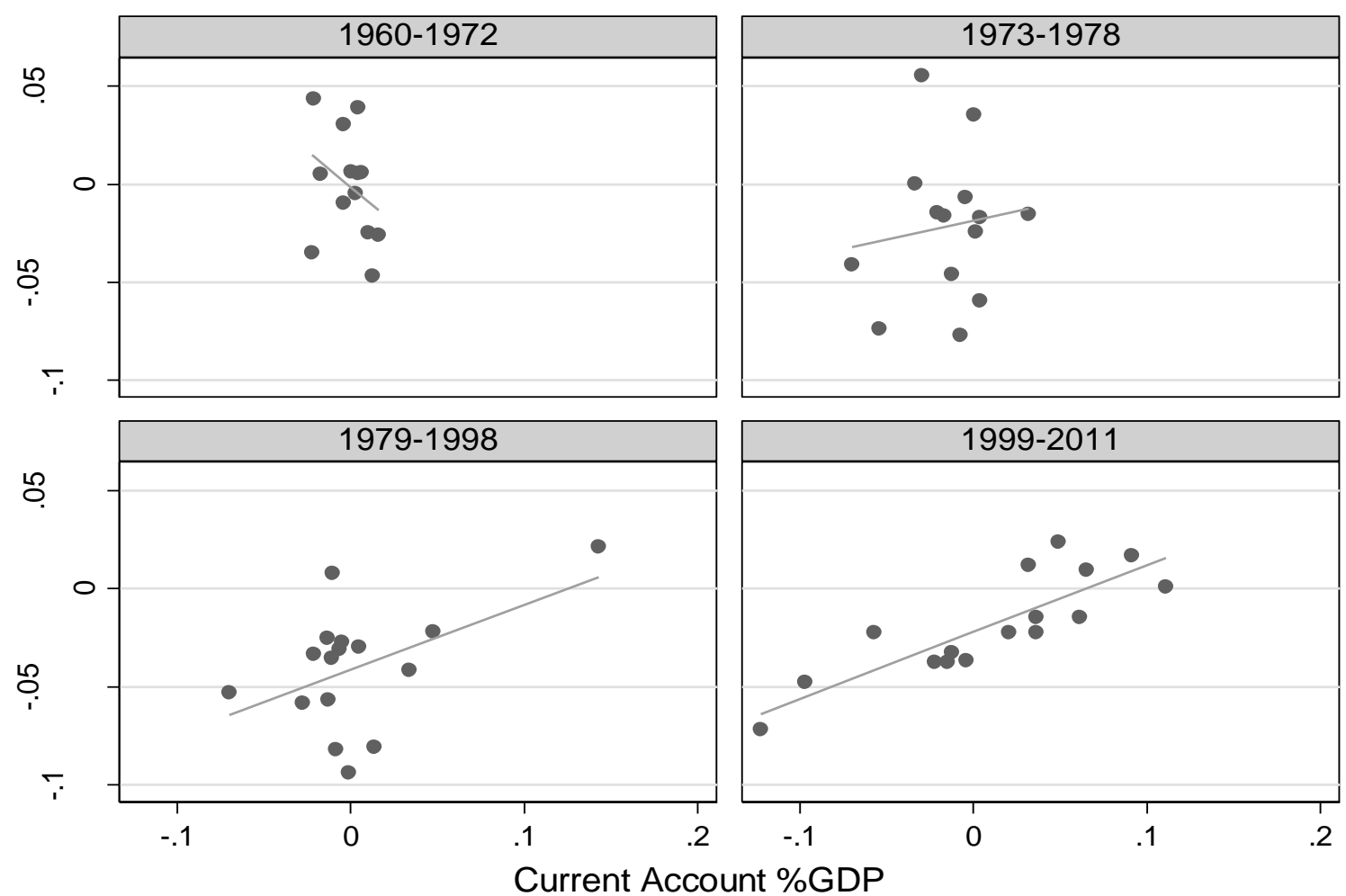

Source: OECD Economic Outlook No. 90, European Commission AMECO database. Straight lines indicate fitted values. 
Table1: Data Description

\begin{tabular}{|c|c|c|}
\hline Acronym & Description & Source \\
\hline$c a$ & current account balance in $\%$ of nominal GDP & $\begin{array}{l}\text { European Commission } \\
\text { AMECO database }\end{array}$ \\
\hline gexp & $\begin{array}{l}\text { cyclically adjusted government expenditure } \\
\text { excluding interest payments in } \% \text { of potential GDP }\end{array}$ & $\begin{array}{l}\text { OECD Economic } \\
\text { Outlook No. } 90\end{array}$ \\
\hline gdef & $\begin{array}{l}\text { cyclically adjusted government net lending in } \% \text { of } \\
\text { potential GDP }\end{array}$ & $\begin{array}{l}\text { OECD Economic } \\
\text { Outlook No. } 90\end{array}$ \\
\hline ireal & $\begin{array}{l}\text { real short-term interest rate (computed as nominal } \\
\text { short-term interest rate minus inflation rate) in \% }\end{array}$ & $\begin{array}{l}\text { OECD Economic } \\
\text { Outlook No. } 90\end{array}$ \\
\hline dexchg & $\begin{array}{l}\text { exchange rate change versus German mark (euro } \\
\text { since 1999), year-end value against previous year- } \\
\text { end value (increase equals depreciation) }\end{array}$ & $\begin{array}{l}\text { IMF International } \\
\text { Financial Statistics }\end{array}$ \\
\hline & $\begin{array}{l}\text { For Germany arithmetic average of changes versus } \\
\text { French Franc, Italian Lira and British Pound }\end{array}$ & \\
\hline dres & $\begin{array}{l}\text { changes of foreign reserves, year-end value against } \\
\text { previous year-end value in } \% \text { of GDP }\end{array}$ & $\begin{array}{l}\text { IMF International } \\
\text { Financial Statistics }\end{array}$ \\
\hline dtarget & $\begin{array}{l}\text { changes in target claims including official rescue } \\
\text { packages in } \% \text { of nominal GDP, year-end value } \\
\text { against previous year-end value }\end{array}$ & $\begin{array}{l}\text { Ifo Institute } \\
\text { (http://www.cesifo- } \\
\text { group.de/ifoHome/polic } \\
\text { y/Haftungspegel.html) }\end{array}$ \\
\hline drulc & $\begin{array}{l}\text { real unit labor costs in total economy, change } \\
\text { against previous year in } \%\end{array}$ & $\begin{array}{l}\text { OECD Economic } \\
\text { Outlook No. } 90\end{array}$ \\
\hline i_us & US federal funds rate in $\%$ & $\begin{array}{l}\text { IMF International } \\
\text { Financial Statistics }\end{array}$ \\
\hline$c a \_u s$ & $\begin{array}{l}\text { US current account balance against Europe in } \% \text { of } \\
\text { US nominal GDP }\end{array}$ & $\begin{array}{l}\text { Bureau of Economic } \\
\text { Analysis, U.S. } \\
\text { Department of } \\
\text { Commerce }\end{array}$ \\
\hline _euro & $\begin{array}{l}\text { dummy }(=1) \text { for membership in the euro area, } \\
\text { otherwise } 0\end{array}$ & \\
\hline _2001 & dummy $(=1)$ for the period after 2001 , otherwise 0 & \\
\hline _core & $\begin{array}{l}\text { dummy }(=1) \text { for countries with structural current } \\
\text { account surpluses since } 1999 \text {, otherwise } 0\end{array}$ & \\
\hline _noneuro & $\begin{array}{l}\text { dummy }(=1) \text { for countries which are not members } \\
\text { of the euro area, otherwise } 0\end{array}$ & \\
\hline _ems & $\begin{array}{l}\text { dummy }(=1) \text { for membership in the EMS or } \\
\text { Exchange Rate Mechanism II, otherwise } 0\end{array}$ & \\
\hline _nonems & $\begin{array}{l}\text { dummy }(=1) \text { for countries being not members of } \\
\text { EMS or Exchange Rate mechanism II, otherwise } 0\end{array}$ & \\
\hline
\end{tabular}


Table 2: Regression Results Cyclically Adjusted Government Expenditure (1973-2011)

\begin{tabular}{|c|c|c|c|c|c|c|}
\hline & (1) & (2) & (2a) & (3) & (4) & (5) \\
\hline \multirow[t]{2}{*}{ gexp } & $-0.387 * * *$ & $-0.340 * * *$ & $-0.378 * * *$ & $-0.330 * * *$ & $-0.338 * * *$ & $-0.349 * * *$ \\
\hline & $(-7.62)$ & $(-6.92)$ & $(-7.54)$ & $(-6.45)$ & $(-6.74)$ & $(-7.07)$ \\
\hline \multirow[t]{2}{*}{ i_real } & 0.063 & -0.008 & 0.050 & -0.015 & -0.010 & -0.006 \\
\hline & $(1.38)$ & $(-0.17)$ & $(1.05)$ & $(-0.34)$ & $(-0.23)$ & $(-0.13)$ \\
\hline \multirow[t]{2}{*}{ dexchg } & -0.357 & $-0.489 * *$ & $-0.400 *$ & $-0.545 * *$ & $-0.570 * *$ & -0.027 \\
\hline & $(-1.49)$ & $(-2.10)$ & $(-1.68)$ & $(-2.42)$ & $(-2.53)$ & $(-0.06)$ \\
\hline \multirow[t]{2}{*}{ dres } & 0.101 & 0.090 & 0.112 & 0.086 & 0.094 & 0.334 \\
\hline & $(1.40)$ & $(1.28)$ & (1.64) & $(1.22)$ & (1.32) & (1.19) \\
\hline \multirow[t]{2}{*}{ dtarget } & 0.064 & $0.118^{* * *}$ & $0.101 * *$ & $0.120 * * *$ & $0.121 * * *$ & $0.121 * * *$ \\
\hline & $(1.40)$ & $(2.89)$ & $(2.32)$ & $(2.88)$ & $(3.12)$ & $(2.95)$ \\
\hline \multirow[t]{2}{*}{ drulc } & $-0.168 * *$ & -0.125 & $-0.156^{*}$ & -0.110 & -0.119 & $-0.140 *$ \\
\hline & $(-2.41)$ & $(-1.60)$ & $(-1.90)$ & $(-1.44)$ & $(-1.53)$ & $(-1.79)$ \\
\hline \multirow[t]{2}{*}{ i_us } & $-0.293 * * *$ & $-0.343 * * *$ & $-0.274 * * *$ & $-0.325^{* * *}$ & $-0.592 * * *$ & $-0.351 * * *$ \\
\hline & $(-6.52)$ & $(-6.94)$ & $(-5.17)$ & $(-6.45)$ & $(-4.16)$ & $(-7.07)$ \\
\hline \multirow{2}{*}{ ca_us } & $-1.021 * * *$ & $-1.092 * * *$ & $-0.839 * * *$ & 0.539 & $-1.340 * * *$ & $-1.102 * * *$ \\
\hline & $(-3.81)$ & $(-4.02)$ & $(-3.07)$ & $(0.78)$ & $(-4.76)$ & $(-4.04)$ \\
\hline \multirow[t]{2}{*}{ gexp_euro } & & $-0.039 * * *$ & & $-0.026^{*}$ & $-0.024 *$ & $-0.037 * * *$ \\
\hline & & $(-3.48)$ & & $(-1.74)$ & $(-1.82)$ & $(-3.20)$ \\
\hline \multirow[t]{2}{*}{ i_real_euro } & & $1.035 * * *$ & & $0.902 * * *$ & $1.200 * * *$ & $1.025 * * *$ \\
\hline & & $(4.84)$ & & $(4.19)$ & $(5.31)$ & $(4.79)$ \\
\hline \multirow[t]{2}{*}{ drulc_euro } & & $-0.395 * *$ & & $-0.383^{* *}$ & $-0.467 * * *$ & $-0.396^{* *}$ \\
\hline & & $(-2.18)$ & & $(-2.25)$ & $(-2.65)$ & $(-2.20)$ \\
\hline \multirow{2}{*}{ gexp_2001 } & & & 0.002 & & & \\
\hline & & & $(0.16)$ & & & \\
\hline \multirow[t]{2}{*}{ i_real_2001 } & & & $0.608 * * *$ & & & \\
\hline & & & $(3.07)$ & & & \\
\hline \multirow[t]{2}{*}{ drulc_2001 } & & & -0.233 & & & \\
\hline & & & $(-1.44)$ & & & \\
\hline \multirow{2}{*}{\multicolumn{4}{|c|}{ ca_us_core }} & $-1.670^{* * *}$ & & \\
\hline & & & & $(-3.03)$ & & \\
\hline \multirow[t]{2}{*}{ ca_us_noneuro } & & & & $-1.502 * *$ & & \\
\hline & & & & $(-2.07)$ & & \\
\hline \multirow[t]{2}{*}{ i_us_core } & & & & & $-0.125^{*}$ & \\
\hline & & & & & $(-1.86)$ & \\
\hline \multirow[t]{2}{*}{ i_us_noneuro } & & & & & $0.319 * *$ & \\
\hline & & & & & $(2.23)$ & \\
\hline \multirow[t]{2}{*}{ dres ems } & & & & & & -0.109 \\
\hline & & & & & & $(-0.36)$ \\
\hline \multirow[t]{2}{*}{ dexchg_nonems } & & & & & & -0.578 \\
\hline & & & & & & $(-1.21)$ \\
\hline \multirow[t]{2}{*}{ dres_nonems } & & & & & & -0.347 \\
\hline & & & & & & $(-1.13)$ \\
\hline observations & 550 & 550 & 550 & 550 & 550 & 550 \\
\hline $\mathrm{R}^{2}$ & 0.65 & 0.67 & 0.66 & 0.68 & 0.68 & 0.68 \\
\hline adjusted $\mathrm{R}^{2}$ & 0.63 & 0.66 & 0.64 & 0.66 & 0.66 & 0.66 \\
\hline
\end{tabular}

Robust $t$ statistics in parentheses.

$p<0.10, * * p<0.05, * * * p<0.01$ 
Table 3: Regression Results Cyclically Adjusted Government Net Lending (1973-2011)

\begin{tabular}{|c|c|c|c|c|c|c|}
\hline & (1) & (2) & (2a) & (3) & (4) & (5) \\
\hline \multirow[t]{2}{*}{ gdef } & $0.237 * * *$ & 0.081 & 0.056 & $0.119^{*}$ & $0.145^{* *}$ & 0.087 \\
\hline & $(3.50)$ & $(1.23)$ & $(0.82)$ & $(1.83)$ & $(2.26)$ & $(1.30)$ \\
\hline \multirow[t]{2}{*}{ i_real } & -0.005 & $-0.083^{*}$ & $-0.090 * *$ & $-0.111^{* *}$ & $-0.112 * * *$ & $-0.082 *$ \\
\hline & $(-0.10)$ & $(-1.86)$ & $(-1.99)$ & $(-2.58)$ & $(-2.63)$ & $(-1.84)$ \\
\hline \multirow[t]{2}{*}{ dexchg } & 0.280 & -0.061 & -0.041 & -0.179 & -0.234 & -0.089 \\
\hline & (1.04) & $(-0.25)$ & $(-0.17)$ & $(-0.78)$ & $(-1.04)$ & $(-0.19)$ \\
\hline \multirow[t]{2}{*}{ dres } & $0.146^{* *}$ & $0.133^{* *}$ & $0.144 * *$ & $0.111^{*}$ & $0.116^{*}$ & $0.435^{*}$ \\
\hline & $(2.06)$ & $(2.01)$ & $(2.32)$ & $(1.65)$ & $(1.72)$ & (1.66) \\
\hline \multirow[t]{2}{*}{ dtarget } & 0.060 & -0.019 & -0.014 & 0.000 & 0.010 & -0.013 \\
\hline & $(0.83)$ & $(-0.23)$ & $(-0.17)$ & $(0.00)$ & $(0.13)$ & $(-0.16)$ \\
\hline \multirow[t]{2}{*}{ drulc } & $-0.155^{* *}$ & -0.101 & -0.099 & -0.076 & -0.083 & -0.110 \\
\hline & $(-1.97)$ & $(-1.25)$ & $(-1.13)$ & $(-0.95)$ & $(-1.04)$ & $(-1.37)$ \\
\hline \multirow[t]{2}{*}{ i_us } & $-0.167 * * *$ & $-0.289 * * *$ & $-0.297 * * *$ & $-0.289 * * *$ & $-0.838 * * *$ & $-0.295 * * *$ \\
\hline & $(-3.88)$ & $(-6.27)$ & $(-6.43)$ & $(-6.27)$ & $(-6.38)$ & $(-6.40)$ \\
\hline \multirow[t]{2}{*}{ ca_us } & -0.497 & -0.389 & -0.380 & $1.848^{* * *}$ & $-0.942 * * *$ & -0.418 \\
\hline & $(-1.57)$ & $(-1.37)$ & $(-1.33)$ & $(3.60)$ & $(-3.25)$ & $(-1.46)$ \\
\hline \multirow[t]{2}{*}{ gdef_euro } & & $0.696 * * *$ & & $0.621 * * *$ & $0.629 * * *$ & $0.690 * * *$ \\
\hline & & $(5.51)$ & & $(5.01)$ & $(5.20)$ & $(5.46)$ \\
\hline \multirow[t]{2}{*}{ i_real_euro } & & $0.903 * * *$ & & $0.935^{* * *}$ & $1.435^{* * *}$ & $0.911 * * *$ \\
\hline & & $(4.94)$ & & $(5.06)$ & $(6.45)$ & $(4.97)$ \\
\hline \multirow[t]{2}{*}{ drulc_euro } & & $-0.400 * *$ & & $-0.459 * *$ & $-0.574 * * *$ & $-0.417 * *$ \\
\hline & & $(-2.01)$ & & $(-2.39)$ & $(-2.86)$ & $(-2.07)$ \\
\hline \multirow[t]{2}{*}{ gdef_2001 } & & & $0.670 * * *$ & & & \\
\hline & & & $(6.17)$ & & & \\
\hline \multirow[t]{2}{*}{ i_real_2001 } & & & $0.853 * * *$ & & & \\
\hline & & & $(5.03)$ & & & \\
\hline \multirow[t]{2}{*}{ drulc_2001 } & & & $-0.376^{* *}$ & & & \\
\hline & & & $(-2.17)$ & & & \\
\hline \multirow[t]{2}{*}{ ca_us_core } & & & & $-1.562 * * *$ & & \\
\hline & & & & $(-3.43)$ & & \\
\hline \multirow[t]{2}{*}{ ca_us_noneuro } & & & & $-2.484 * * *$ & & \\
\hline & & & & $(-4.72)$ & & \\
\hline \multirow[t]{2}{*}{ i_us_core } & & & & & -0.086 & \\
\hline & & & & & $(-1.24)$ & \\
\hline \multirow[t]{2}{*}{ i_us_noneuro } & & & & & $0.595^{* * *}$ & \\
\hline & & & & & $(4.81)$ & \\
\hline \multirow[t]{2}{*}{ dres ems } & & & & & & -0.223 \\
\hline & & & & & & $(-0.78)$ \\
\hline \multirow[t]{2}{*}{ dexchg_nonems } & & & & & & -0.003 \\
\hline & & & & & & $(-0.00)$ \\
\hline \multirow[t]{2}{*}{ dres_nonems } & & & & & & -0.397 \\
\hline & & & & & & $(-1.38)$ \\
\hline observations & $-0.012 *$ & -0.002 & -0.003 & 0.004 & 0.003 & -0.001 \\
\hline & $(-1.69)$ & $(-0.27)$ & $(-0.40)$ & $(0.59)$ & $(0.43)$ & $(-0.13)$ \\
\hline \multirow{3}{*}{ adjusted $\mathrm{R}^{2}$} & 546 & 546 & 546 & 546 & 546 & 546 \\
\hline & 0.61 & 0.67 & 0.67 & 0.68 & 0.69 & 0.67 \\
\hline & 0.59 & 0.65 & 0.65 & 0.67 & 0.67 & 0.65 \\
\hline
\end{tabular}

Robust $t$ statistics in parentheses

$* p<0.10, * * p<0.05, * * * p<0.01$ 
Table 4: Regression Results Cyclically Adjusted Government Expenditure (1999-2011)

\begin{tabular}{|c|c|c|c|c|c|c|}
\hline & (1) & (2) & (2a) & (3) & (4) & (5) \\
\hline \multirow[t]{2}{*}{ gexp } & $-0.602 * * *$ & $-0.493 * * *$ & $-0.583^{* * *}$ & $-0.484 * * *$ & $-0.517 * * *$ & $-0.339 * * *$ \\
\hline & $(-6.10)$ & $(-4.63)$ & $(-5.49)$ & $(-4.78)$ & $(-4.79)$ & $(-3.50)$ \\
\hline \multirow[t]{2}{*}{ i_real } & 0.171 & -0.199 & -0.004 & -0.228 & -0.322 & -0.204 \\
\hline & $(1.24)$ & $(-1.21)$ & $(-0.01)$ & $(-1.11)$ & $(-1.34)$ & $(-1.38)$ \\
\hline \multirow[t]{2}{*}{ dexchg } & $1.092^{* *}$ & $0.953 *$ & $1.114^{* *}$ & $0.934 *$ & $0.982^{*}$ & $-30.757 * * *$ \\
\hline & $(2.08)$ & $(1.81)$ & $(1.98)$ & $(1.84)$ & $(1.83)$ & $(-6.64)$ \\
\hline \multirow[t]{2}{*}{ dres } & 0.147 & 0.145 & $0.153^{*}$ & 0.153 & 0.163 & -0.027 \\
\hline & $(1.65)$ & (1.54) & $(1.71)$ & $(1.48)$ & (1.53) & $(-0.23)$ \\
\hline \multirow[t]{2}{*}{ dtarget } & -0.022 & -0.025 & -0.021 & -0.034 & -0.020 & -0.031 \\
\hline & $(-0.95)$ & $(-1.15)$ & $(-0.89)$ & $(-1.55)$ & $(-0.87)$ & $(-1.43)$ \\
\hline \multirow[t]{2}{*}{ drulc } & $-0.296 * * *$ & -0.206 & -0.191 & -0.185 & -0.192 & $-0.235^{*}$ \\
\hline & $(-3.83)$ & $(-1.47)$ & $(-0.96)$ & $(-1.25)$ & $(-1.40)$ & $(-1.89)$ \\
\hline \multirow[t]{2}{*}{ i_us } & $-0.305 * * *$ & $-0.302 * * *$ & $-0.344 * * *$ & $-0.312 * * *$ & $-0.363 * * *$ & $-0.272 * * *$ \\
\hline & $(-3.52)$ & $(-3.67)$ & $(-3.47)$ & $(-3.71)$ & $(-3.11)$ & $(-3.31)$ \\
\hline \multirow[t]{2}{*}{ ca_us } & -0.031 & -0.185 & -0.102 & -0.844 & -0.212 & -0.151 \\
\hline & $(-0.07)$ & $(-0.41)$ & $(-0.21)$ & $(-1.34)$ & $(-0.45)$ & $(-0.34)$ \\
\hline \multirow{2}{*}{ gexp_euro } & & $-0.123^{*}$ & & $-0.131 *$ & -0.114 & $-0.264 * * *$ \\
\hline & & $(-1.77)$ & & $(-1.86)$ & $(-1.56)$ & $(-6.66)$ \\
\hline \multirow[t]{2}{*}{ i_real_euro } & & $0.426^{* *}$ & & $0.520^{* *}$ & $0.574^{*}$ & $0.402^{*}$ \\
\hline & & $(2.01)$ & & $(2.22)$ & (1.93) & $(1.96)$ \\
\hline \multirow[t]{2}{*}{ drulc_euro } & & -0.078 & & -0.134 & -0.099 & -0.027 \\
\hline & & $(-0.48)$ & & $(-0.79)$ & $(-0.63)$ & $(-0.18)$ \\
\hline \multirow[t]{2}{*}{ gexp_2001 } & & & -0.017 & & & \\
\hline & & & $(-0.86)$ & & & \\
\hline \multirow[t]{2}{*}{ i_real_2001 } & & & 0.205 & & & \\
\hline & & & $(0.59)$ & & & \\
\hline \multirow[t]{2}{*}{ drulc_2001 } & & & -0.110 & & & \\
\hline & & & $(-0.49)$ & & & \\
\hline \multirow[t]{2}{*}{ ca_us_core } & & & & $1.496^{*}$ & & \\
\hline & & & & $(1.85)$ & & \\
\hline \multirow[t]{2}{*}{ ca_us_noneuro } & & & & 0.336 & & \\
\hline & & & & $(0.27)$ & & \\
\hline \multirow[t]{2}{*}{ i_us_core } & & & & & 0.052 & \\
\hline & & & & & $(0.34)$ & \\
\hline \multirow[t]{2}{*}{ i_us_noneuro } & & & & & 0.171 & \\
\hline & & & & & $(0.74)$ & \\
\hline \multirow[t]{2}{*}{ dres ems } & & & & & & 0.071 \\
\hline & & & & & & $(0.47)$ \\
\hline \multirow[t]{2}{*}{ dexchg_nonems } & & & & & & $31.883 * * *$ \\
\hline & & & & & & $(6.75)$ \\
\hline \multirow[t]{2}{*}{ dres_nonems } & & & & & & 0.239 \\
\hline & & & & & & $(1.43)$ \\
\hline observations & 195 & 195 & 195 & 195 & 195 & 195 \\
\hline $\mathrm{R}^{2}$ & 0.92 & 0.93 & 0.93 & 0.93 & 0.93 & 0.93 \\
\hline adjusted $\mathrm{R}^{2}$ & 0.92 & 0.92 & 0.91 & 0.92 & 0.92 & 0.92 \\
\hline
\end{tabular}

Robust $t$ statistics in parentheses

$* p<0.10, * * p<0.05, * * * p<0.01$ 
Table 5: Regression Results Cyclically Adjusted Government Net Lending (1999-2011)

\begin{tabular}{|c|c|c|c|c|c|c|}
\hline & (1) & (2) & (2a) & (3) & (4) & (5) \\
\hline \multirow[t]{2}{*}{ gdef } & $0.212 * * *$ & -0.013 & 0.045 & -0.025 & -0.019 & -0.088 \\
\hline & $(2.61)$ & $(-0.09)$ & $(0.21)$ & $(-0.17)$ & $(-0.13)$ & $(-0.49)$ \\
\hline \multirow[t]{2}{*}{ i_real } & 0.125 & 0.183 & 0.132 & 0.321 & 0.093 & 0.258 \\
\hline & $(0.71)$ & $(0.57)$ & $(0.41)$ & $(0.91)$ & $(0.27)$ & $(0.73)$ \\
\hline \multirow[t]{2}{*}{ dexchg } & $0.898^{*}$ & 0.656 & $0.890 *$ & 0.691 & 0.655 & -2.904 \\
\hline & $(1.85)$ & $(1.23)$ & $(1.65)$ & $(1.29)$ & $(1.24)$ & $(-0.44)$ \\
\hline \multirow[t]{2}{*}{ dres } & 0.140 & 0.123 & 0.144 & 0.111 & 0.135 & -0.130 \\
\hline & (1.59) & $(1.26)$ & (1.64) & (1.06) & $(1.26)$ & $(-0.94)$ \\
\hline \multirow[t]{2}{*}{ dtarget } & -0.035 & -0.043 & -0.039 & $-0.054 *$ & -0.042 & -0.049 \\
\hline & $(-1.08)$ & $(-1.35)$ & $(-1.22)$ & $(-1.67)$ & $(-1.26)$ & $(-1.56)$ \\
\hline \multirow[t]{2}{*}{ drulc } & $-0.299 * * *$ & -0.200 & -0.253 & $-0.251^{*}$ & -0.184 & -0.181 \\
\hline & $(-3.74)$ & $(-1.47)$ & $(-0.96)$ & $(-1.68)$ & $(-1.39)$ & $(-1.40)$ \\
\hline \multirow[t]{2}{*}{ i_us } & $-0.242 * *$ & $-0.250 * * *$ & $-0.250 * *$ & $-0.275^{* * *}$ & $-0.271^{*}$ & $-0.236 * *$ \\
\hline & $(-2.46)$ & $(-2.62)$ & $(-2.34)$ & $(-2.86)$ & $(-1.94)$ & $(-2.44)$ \\
\hline \multirow[t]{2}{*}{ ca_us } & $-0.780^{*}$ & -0.720 & $-0.778^{*}$ & $-1.712 * * *$ & -0.757 & -0.683 \\
\hline & $(-1.74)$ & $(-1.54)$ & $(-1.67)$ & $(-2.61)$ & $(-1.56)$ & $(-1.46)$ \\
\hline \multirow[t]{2}{*}{ gdef_euro } & & 0.272 & & 0.281 & 0.284 & 0.331 \\
\hline & & (1.56) & & (1.58) & $(1.62)$ & $(1.55)$ \\
\hline \multirow[t]{2}{*}{ i_real_euro } & & -0.053 & & -0.106 & 0.057 & -0.148 \\
\hline & & $(-0.16)$ & & $(-0.30)$ & $(0.15)$ & $(-0.41)$ \\
\hline \multirow[t]{2}{*}{ drulc_euro } & & -0.123 & & -0.105 & -0.145 & -0.118 \\
\hline & & $(-0.77)$ & & $(-0.61)$ & $(-0.93)$ & $(-0.73)$ \\
\hline \multirow[t]{2}{*}{ gdef_2001 } & & & 0.177 & & & \\
\hline & & & $(0.84)$ & & & \\
\hline \multirow[t]{2}{*}{ i_real_2001 } & & & -0.031 & & & \\
\hline & & & $(-0.10)$ & & & \\
\hline \multirow[t]{2}{*}{ drulc_2001 } & & & -0.048 & & & \\
\hline & & & $(-0.16)$ & & & \\
\hline \multirow[t]{2}{*}{ Ca_us_core } & & & & $1.738^{*}$ & & \\
\hline & & & & $(1.90)$ & & \\
\hline \multirow[t]{2}{*}{ Ca_us_noneuro } & & & & 1.517 & & \\
\hline & & & & $(1.31)$ & & \\
\hline \multirow[t]{2}{*}{ i_us_core } & & & & & -0.009 & \\
\hline & & & & & $(-0.05)$ & \\
\hline \multirow[t]{2}{*}{ i_us_noneuro } & & & & & 0.100 & \\
\hline & & & & & $(0.47)$ & \\
\hline \multirow[t]{2}{*}{ dres ems } & & & & & & 0.117 \\
\hline & & & & & & $(0.61)$ \\
\hline \multirow[t]{2}{*}{ dexchg_nonems } & & & & & & 3.758 \\
\hline & & & & & & $(0.57)$ \\
\hline \multirow[t]{2}{*}{ dres_nonems } & & & & & & $0.370^{* *}$ \\
\hline & & & & & & $(2.13)$ \\
\hline observations & 195 & 195 & 195 & 195 & 195 & 195 \\
\hline $\mathrm{R}^{2}$ & 0.91 & 0.91 & 0.91 & 0.91 & 0.91 & 0.91 \\
\hline adjusted $\mathrm{R}^{2}$ & 0.90 & 0.90 & 0.90 & 0.90 & 0.90 & 0.90 \\
\hline
\end{tabular}

Robust $t$ statistics in parentheses

$* p<0.10, * * p<0.05, * * * p<0.01$ 